\title{
Evolution and Management of the Irish Potato Famine Pathogen Phytophthora infestans in Canada and the United States
}

\author{
Yeen Ting Hwang • Champa Wijekoon • \\ Melanie Kalischuk • Dan Johnson • Ron Howard • \\ Dirk Prüfer $\cdot$ Lawrence Kawchuk
}

Published online: 9 July 2014

(C) The Author(s) 2014. This article is published with open access at Springerlink.com

\begin{abstract}
Late blight, caused by Phytophthora infestans (Mont.) de Bary, is the most historically significant and economically destructive disease of potatoes (Solanum tuberosum L.). In addition to potato, P. infestans can also infect tomato and some other members of the Solanaceae, and this has contributed to the recent late blight epidemic in Canada and the United States. Propagation of $P$. infestans in Canada and the United States has been mainly through asexual reproduction and this has led to the development of several dominant clonal lineages. Various $P$. infestans markers have been developed that are invaluable in monitoring the evolution and movement of these $P$. infestans genotypes. Population diversity and disease incidence has increased through the development of systemic fungicide insensitivity and the transcontinental shipment of the pathogen on late blight infected potato tubers and tomato plantlets. Introduction of the P. infestans A2 mating type to several regions of Canada and the United States has also increased the opportunity for sexual reproduction and
\end{abstract}

\footnotetext{
Y. T. Hwang $\cdot$ C. Wijekoon $・$ L. Kawchuk $(\triangle)$

Lethbridge Research Centre, Agriculture and Agri-Food Canada,

5403-1 Avenue South, Lethbridge, AB T1J 4B1, Canada

e-mail: lawrence.kawchuk@agr.gc.ca

M. Kalischuk · D. Johnson

University of Lethbridge, 4401 University Drive West, Lethbridge, AB T1K 3M4, Canada

R. Howard

Crop Diversification Centre South, Alberta Agriculture and Rural Development, 301 Horticultural Station Road East, Brooks, AB T1R 1E6, Canada

\section{Prüfer}

Institut für Biologie und Biotechnologie der Pflanzen Fraunhofer IME - Außenstelle Münster, Westfälische Wilhelms-Universität Münster, Schlossplatz 8 (vormals Hindenburgplatz 55),

Münster 48143, Germany
}

recombination, potentially contributing to greater $P$. infestans genetic diversity and pathogenicity. Advances in P. infestans molecular analysis have revealed a complex pathogen with a genome capable of evolving relatively quickly. Management of late blight will therefore require new, multifaceted strategies which include monitoring pathogen evolution and implementing sustainable production practices.

Resumen El tizón tardío, causado por Phytophthora infestans (Mont.) de Bary, es la enfermedad históricamente más significativa y económicamente destructiva de papa (Solanum tuberosum L.). Además de la papa, P. infestans también puede infectar tomate y a otros miembros de la familia Solanaceae, y esto ha contribuido a la reciente epidemia de tizón tardío en Canadá y los Estados Unidos. La propagación de P.infestans en estos dos países ha sido principalmente mediante reproducción asexual, lo que ha conducido al desarrollo de varias líneas clonales dominantes. Se han desarrollado varios marcadores para $P$. infestans que son invaluables en el seguimiento de la evolución y movimiento de estos genotipos de P. infestans. La diversidad de la población y la incidencia de la enfermedad han aumentado por vía del desarrollo de la insensibilidad a fungicidas sistémicos y del envío transcontinental del patógeno en tubérculos de papa infectados con tizón tardío y en plántulas de tomate. La introducción del tipo de compatibilidad A2 de $P$. infestans a varias regiones de Canadá y Estados Unidos también ha incrementado la oportunidad de reproducción sexual y recombinación, contribuyendo, potencialmente, a una mayor diversidad genética y patogenicidad de $P$. infestans. Avances en los análisis moleculares de $P$. infestans han revelado a un patógeno complejo con un genomio capaz de evolucionar relativamente rápido. El manejo del tizón tardío, entonces, requerirá de nuevas estrategias multifacéticas que incluyan monitoreo de la evolución del patógeno y la implementación de prácticas sustentables de producción. 
Keywords Late blight $\cdot$ Genetic diversity $\cdot$ Solanum tuberosum $\cdot$ Disease prevention

\section{Introduction}

Late blight is a common and potentially devastating disease of potatoes (Solanum tuberosum L.) caused by the fungal-like pathogen Phytophthora infestans (Mont.) de Bary. Endemic to Central and possibly South America, its introduction into North America and Europe has led to pathogen population explosions which have caused a series of crop failures over the past two centuries (Bourke 1964; Fry 2008; Goodwin et al. 1994b; Yoshida et al. 2013). Late blight is infamous for its role in the Irish potato famine of the $1840 \mathrm{~s}$ and the disease remains a major cause of significant, worldwide potato crop losses. The pathogen also infects tomato (Solanum lycopersicon L.) and other crop, weedy, and ornamental members of the Solanaceae (Platt 1999). Although worldwide crop losses have more recently been averted through disease management strategies and preventative fungicide treatments, economic losses are still estimated at several billion dollars per annum (Haverkort et al. 2008).

$P$. infestans belongs to the oomycetes, a destructive group of non-photosynthetic eukaryotes that are closely related to the brown algae and diatoms (Sogin and Silberman 1998). $P$. infestans may infect all parts of the plant, including stems, leaves, fruits, and tubers (Fig. 1). The pathogen is capable of penetrating a healthy tuber periderm which reduces yield and quality and diminishes storability by facilitating secondary infections (Smart and Fry 2001). The pathogen reproduces predominantly by asexual means in the United States and Canada via sporangia formation on infected host tissues which are readily dispersed by wind and rain (Goodwin et al. 1998; Hu et al. 2012; Kalischuk et al. 2012). These sporangia then directly initiate infection or form motile zoospores. The nearobligate pathogen often survives from season to season in infected volunteers and culled potato tubers. $P$. infestans is a heterothallic species with two compatible mating types, A1 and A2 (Cohen et al. 1997). Coexistence of both mating types in close proximity is usually required for sexual reproduction to occur and to allow for the formation of thick-walled resting oospores that may remain viable in the soil for many years in the absence of host tissues (Mayton et al. 2000). The presence of sexual recombination increases both the genetic variation in $P$. infestans populations and the survivability of the pathogen.

\section{Late Blight Population Genetic Diversity}

The late blight epidemic that has occurred over the past 5 years in the United States and Canada represents a population explosion resulting from rapid asexual reproduction of
P. infestans on susceptible host tissues under favorable conditions that include high humidity and cool temperatures (Fry and Goodwin 1997b). Because these initial infections may be difficult to detect, and given the short latency period under favorable conditions, the total devastation of infected plants may occur within a few days. However, there are effective management strategies for preventing late blight, which include the timely detection of early symptoms, knowledge of weather conditions, effective fungicide spray programs, removal of possible primary inoculum sources, and the introduction of host resistance (Fry 2008).

All members of a clonal lineage are asexual descendants of a single individual and variation may occur through mutation or mitotic recombination (Anderson and Kohn 1995). A standardized framework has been developed to classify clonal lineages of $P$. infestans based on phenotypic and genotypic markers (Forbes et al. 1998; Cooke and Lees 2004). All members of a $P$. infestans genotype, that may include several different clonal lineages, exhibit many of the same characteristics. Thus, identification can assist in tracking movement of the pathogen and preventing disease losses. Genetic analysis of $P$. infestans populations has facilitated a proactive approach in the application of sustainable disease management practices that involve the elimination of specific pathogen genotypes and the selection of effective fungicides. Phenotypic markers available for characterizing $P$. infestans isolates include mating type (A1 or A2) (Gallegly and Galindo 1958), virulence (Malcolmson and Black 1966; Malcolmson 1969; Cooke et al. 2003), host preference (Kalischuk et al. 2012; Danies et al. 2013), and resistance or sensitivity to the fungicide metalaxyl (Dowley and O'Sullivan 1981; Fry et al. 1993).

Genotypic markers routinely used to characterize $P$. infestans isolates include the allozyme glucose-6phosphate isomerase [Gpi] and peptidase [Pep] loci profiles (Tooley et al. 1985; Spielman et al. 1991; Goodwin et al. 1998), mitochondrial DNA (mtDNA) haplotype Ia, Ib, IIa and IIb markers (Carter et al. 1990; Griffith and Shaw 1998), and genomic DNA restriction fragment length polymorphism (RFLP) analysis with moderately repetitive nuclear DNA sequence RG57 (Goodwin et al. 1992) (Fig. 2). Although the allozyme assay may be applied to sporangia from a sporulating lesion, this technique has a relatively limited discriminatory ability. For example, the Gpi profiles of the $P$. infestans US-6 and US-23 or US-11 and US-24 genotypes are identical (Table 1). Analysis by RFLP provides greater resolution of $P$. infestans genotypes with well-characterized markers that are conserved and stringent but it also requires the isolation and propagation of the pathogen, a process that often takes weeks or months to complete (Goodwin et al. 1992; Hausner et al. 2000). Most recently, analysis of simple sequence repeats (SSRs) has been used to distinguish the P. infestans genotypes (Knapova and Gisi 2002; Lees et al. 2006). This PCR-based method may be used on small samples 
Fig. 1 Late blight symptoms associated with the infection of potato and tomato by

Phytophthora infestans. a A

$P$. infestans infected potato leaf exhibiting necrosis and mycelial growth producing sporangia from the leading edge of the diseased tissue. $\mathbf{b}$ Tomato fruit from a backyard garden infected by the P. infestans US-23 genotype that is more aggressive on tomato than potato. This $P$. infestans genotype is often observed infecting potato and tomato fruit in field samples. c Late blight on a potato tuber produces necrotic brown tissue initially located close to the periderm. d A tomato stem from the field showing necrotic lesions from a $P$. infestans US-23 genotype infection, a characteristic usually associated with this clonal lineage. e An example of a potato field infected with the $P$. infestans US-23 genotype showing early symptoms of late blight infection with necrotic tissue on plants radiating out from the initial infection foci
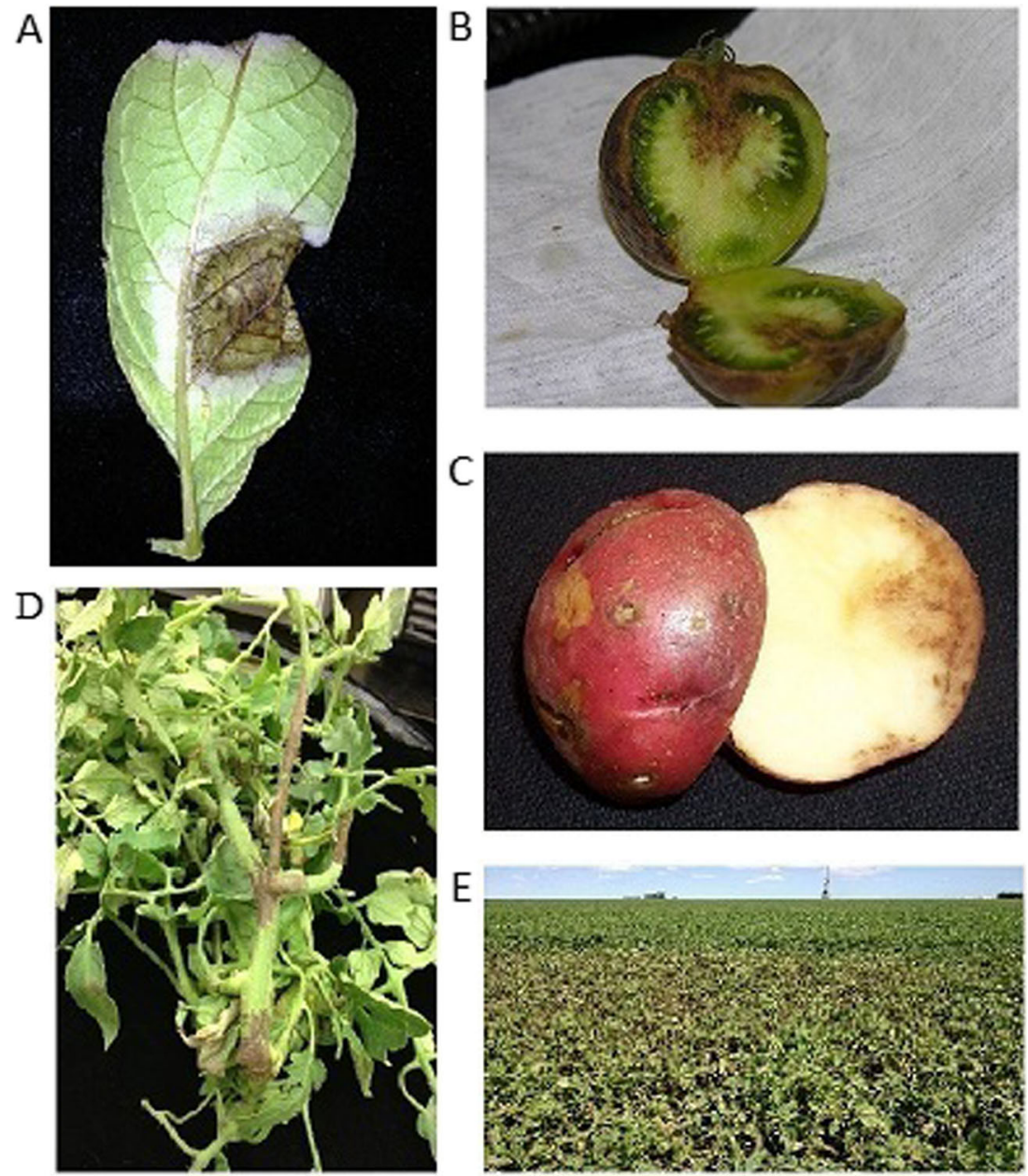

and sporangia from a lesion, and thereby facilitate the rapid identification of a P. infestans genotype (Cooke and Lee 2004; Lees et al. 2006; Danies et al. 2013). However, the SSR sequences are inherently hypervariable and a single $P$. infestans genotype often produces more than one allelic pattern (Danies et al. 2013). It is therefore often necessary to perform multiple analyses with several procedures to clearly determine the genotype of a specific $P$. infestans isolate.

\section{Evolution of Late Blight Populations in United States and Canada}

Several lines of evidence indicate that $P$. infestans originated in the central highlands of Toluca Mexico (Goodwin et al. 1994b; Grünwald et al. 2001). The genotypic diversity of pathogen populations from this region is much greater than pathogen populations elsewhere in the world. This variation is evident from virulence differences producing races, allozyme allelic polymorphism, mating types, mtDNA haplotypes and genomic profiles with the RG57 probe and microsatellite markers (Grünwald and Flier 2005). The genetic variation observed in P. infestans populations in the highlands of central Mexico provides strong genetic evidence that the pathogen was the progeny of sexual recombination. Consistent with this observation is that both mating types of $P$. infestans isolates were found in the same geographic area, thereby increasing the opportunities for sexual reproduction (Gallegly and Galindo 1958; Grünwald and Flier 2005).

The spread of $P$. infestans from central Mexico into the United States and then to Europe had contributed to the Irish potato famine in the 1840s (Goodwin et al. 1994b). The continued spread of the $P$. infestans US-1 genotype in the nineteenth century subsequently led to the worldwide distribution of late blight (Fry et al. 1993). Prior to the 1980s, the only clonal lineage detected in potato-growing areas outside of Mexico consisted exclusively of the US-1 genotype or "old population", which had the A1 mating type (Hohl and Iselin 1984; Goodwin et al. 1994b). Therefore, in most parts of the world, $P$. infestans populations were limited to asexual reproduction (Fry and Goodwin 1997a). Since then, a second migration that included mating type A2 from Mexico had produced dramatic changes in the pathogen populations that had previously consisted exclusively of the A1 mating type in 
A

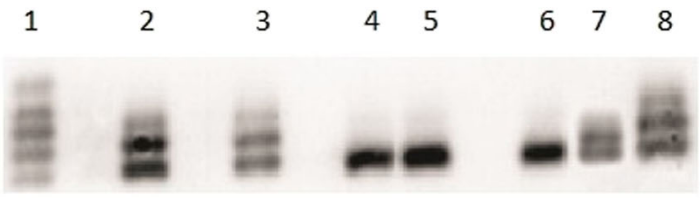

B

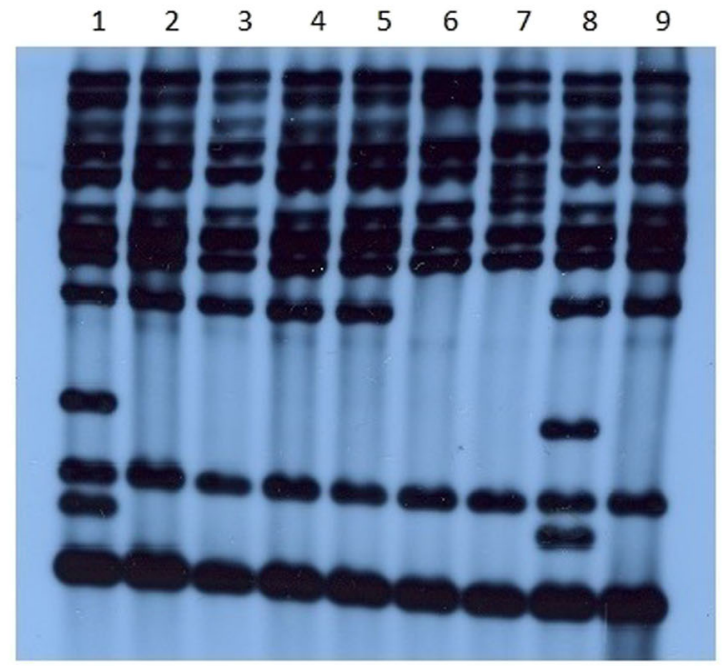

C
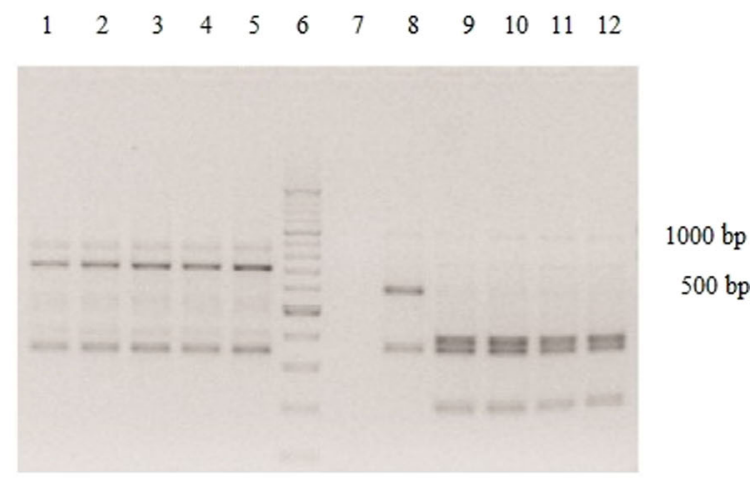

$\mathrm{D}$
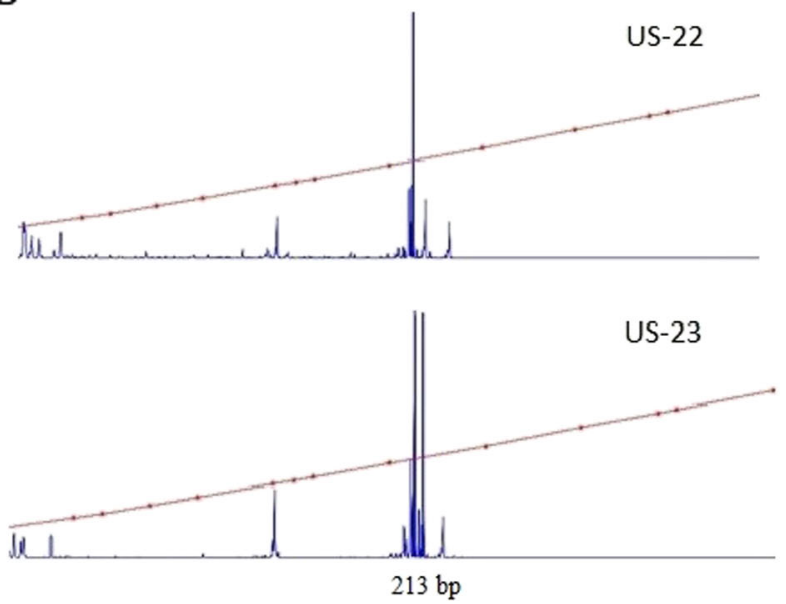

Europe (Hohl and Iselin 1984; Spielman et al. 1991), Asia (Mosa et al. 1993), and North America (Fry et al. 1993).
Fig. 2 Biochemical and molecular markers utilized to identify Phytophthora infestans genotypes. a Glucose-6-phosphate isomerase (Gpi) allozyme profile of $P$. infestans isolates from infected potato and tomato samples collected in 2011. Allozymes were separated on cellulose-acetate gels and stained for Gpi activity. The Gpi profiles of the P. infestans genotypes collected include US-8, Gpi 100/111/122 (lane 1); US-11, Gpi 100/100/111 (lanes 2, 7 and 8); US-23, Gpi 100/100 (Lanes 5 and 6); and US-24, Gpi 100/100/111 (lane 3). The Gpi genotype of US-11 is identical to that of US-24 (Gpi 100/100/111). b Restriction fragment length polymorphic (RFLP) profile of $P$. infestans isolates recovered from infected potato and tomato samples collected in 2011. P. infestans genotypes US-8 (lanes 2, 3, 4, 5 and 9), US-22 (lane 6), a variant clonal lineage US-22.1 (lane 7), and US-24 (lanes 1 and 8) were determined using the RG57 probe to detect homologous EcoRI restricted genomic DNA products. c Amplified DNA products P2 (lanes 1 to 5) and P4 (lanes 8 to 12) containing variable sequences from the mitochondrial genome of $P$. infestans isolates. Amplicons are shown following restriction digestion with $M s p I$ (lanes 1 to 5) or EcoRI (lanes 8 to 12) and gel electrophoresis. Four mitochondrial DNA haplotypes of $P$. infestans designated as Ia, Ib, IIa or IIb have been previously identified through DNA amplification and restriction. All isolates of P. infestans US-8, US-22, US-23, US-24, CA-9, CA-10 and CA-11 genotypes produced the mtDNA haplotype Ia (lanes 2 to 5 and 9 to 12) and all US-11 isolates were mtDNA haplotype IIb (lanes 1 and 8). Lane 6 shows a $100 \mathrm{bp}$ DNA ladder (Fermentas, ON). d) Microsatellite amplification products produced with 6-FAM-labelled oligonucleotides specific to Pi4B and analyzed with an ABI 3730xl capillary system. The $P$. infestans genotypes US-22 and US-23 may be distinguished by the microsatellite sequence Pi4B that gives dominant peaks with sizes of approximately 213 bp or 213 and 217 bp in size, respectively

In contrast to parts of Europe and Mexico where pathogen populations are genetically very diverse, the genetic structures of $P$. infestans in the United States and Canada remain mostly composed of clonal lineages with mating types A1 or A2 separated geographically with few opportunities for sexual reproduction (Goodwin et al. 1995, 1998). However, evidence of possible sexual reproduction has been reported in British Columbia and the Columbia Basin of Washington and Oregon (Gavino et al. 2000; Goodwin 1997; Goodwin et al. 1996) and the opportunity for sexual recombination has increased considerably since 2009 in the United States and Canada with both mating types of $P$. infestans having been discovered in close proximity (Fig. 3). Moreover, we have recently observed multiple recombination events in several $P$. infestans isolates from Ontario, in addition to the A1 and A2 mating types, found in relatively close proximity on tomatoes (Kalischuk et al. 2012; Peters et al. 2014). Perhaps tomato is a preferred host for increased $P$. infestans recombination and the generation of new genotypes with challenging characteristics.

The $P$. infestans US- 1 genotype (pathogenic to potato) of mating type A1 remained the predominant genotype in the United States and Canada until late 1987 when other lineages began to emerge (Goodwin et al. 1995). Genotypes US-3 and CA-1 appeared to be closely related to US-1 and might have been introduced together from the same source population in Mexico (Goodwin et al. 1994a). Analyses of variants within the clonal lineage of US-1 genotypes revealed that they were 
Table 1 Summary of the mating type, mitochondrial haplotype, Gpi allozymes, RG57 RFLP profiles, and metalaxyl sensitivity for Phytophtophora infestans isolates identified in the United States and Canada

\begin{tabular}{|c|c|c|c|c|c|c|c|}
\hline Genotype & Mating type & mtDNA & Host & $G p i$ & Pep & RG57 Profile & Metalaxyl sensitivity \\
\hline US-1 & A1 & $\mathrm{Ib}$ & $\mathrm{P}$ & $86 / 100$ & $92 / 100$ & $1,3,4,5,7,9,10,13,14,16,20,21,24,25$ & $\mathrm{~S}$ \\
\hline US-1.1 & A1 & $\mathrm{Ib}$ & $\mathrm{P}$ & $86 / 100$ & $100 / 100$ & $1,3,4,5,7,9,10,13,14,16,20,21,24,25$ & \\
\hline US-1.2 & A1 & $\mathrm{Ib}$ & $\mathrm{P}$ & $86 / 100$ & $92 / 100$ & $1,3,4,5,7,9,13,14,16,20,21,24,25$ & \\
\hline US-1.3 & A1 & $\mathrm{Ib}$ & $\mathrm{P}$ & $86 / 100$ & $92 / 100$ & $1,3,4,5,7,10,13,14,16,20,21,24,25$ & \\
\hline US-1.4 & A1 & $\mathrm{Ib}$ & $\mathrm{P}$ & $86 / 100$ & $100 / 100$ & $1,3,4,5,7,9,13,14,16,20,21,24,25$ & \\
\hline US-1.5 & A1 & $\mathrm{Ib}$ & $\mathrm{P}$ & $86 / 100$ & $92 / 100$ & $1,3,4,5,7,9,10,13,14,16,18,20,21,24,25$ & \\
\hline US-1.6 & A1 & $\mathrm{Ib}$ & $\mathrm{P}$ & $86 / 100$ & $92 / 100$ & $1,3,4,5,7,9,10,13,14,16,20,21,22,24,25$ & \\
\hline US-1.7 & A1 & $\mathrm{Ib}$ & $\mathrm{P}$ & $100 / 100$ & $92 / 100$ & $1,3,4,5,7,9,10,13,14,16,20,21,24,25$ & \\
\hline US-1.8 & A1 & $\mathrm{Ib}$ & $\mathrm{P}$ & $86 / 100$ & $92 / 100$ & $1,3,4,5,9,10,13,14,16,20,21,24,25$ & \\
\hline US-2 & A1 & & & $86 / 100$ & $92 / 100$ & $1,3,4,5,7,10,13,14,16,18,19,20,21,24,25$ & \\
\hline US-3 & A1 & & & $86 / 100$ & $92 / 100$ & $1,3,4,5,13,14,16,20,21,24,25$ & \\
\hline US-4 & A1 & & $\mathrm{T}$ & $100 / 100$ & $92 / 92$ & $1,3,4,5,7,10,13,14,16,17,20,21,24,25$ & \\
\hline US-5 & A1 & & & $100 / 100$ & $92 / 100$ & $1,3,4,5,7,10,13,14,16,18,19,20,21,24,25$ & $\mathrm{~S}$ \\
\hline US-6 & A1 & $\mathrm{IIb}$ & $\mathrm{T}, \mathrm{P}$ & $100 / 100$ & $92 / 100$ & $1,3,4,5,6,7,10,13,14,18,20,21,24,25$ & $\mathrm{~S}, \mathrm{R}$ \\
\hline US-6.1 & A1 & $\mathrm{IIb}$ & & $100 / 100$ & $92 / 92$ & $1,3,4,5,6,7,10,13,14,18,20,21,24,25$ & \\
\hline US-6.2 & A1 & $\mathrm{IIb}$ & & $100 / 100$ & $92 / 100$ & $1,3,4,5,7,10,13,14,18,20,21,24,25$ & I \\
\hline US-6.3 & A1 & $\mathrm{IIb}$ & & $100 / 100$ & $92 / 100$ & $1,3,4,5,6,7,10,11,12,13,18,20,21,24,25$ & $\mathrm{R}$ \\
\hline US-6.4 & A1 & $\mathrm{IIb}$ & & $100 / 100$ & $100 / 100$ & $1,3,4,6,7,10,13,14,18,20,21,24,25$ & $\mathrm{R}$ \\
\hline US-6.5 & A1 & $\mathrm{IIb}$ & & $100 / 100$ & $92 / 100$ & $1,3,4,5,6,7,10,13,14,18,21,24,25$ & $\mathrm{R}$ \\
\hline US-7 & A2 & Ia & $\mathrm{P}$ & $100 / 111$ & $100 / 100$ & $1,4,5,10,13,14,16,18,20,21,24,25$ & $\mathrm{I}, \mathrm{R}$ \\
\hline US-8 & $\mathrm{A} 2$ & Ia & $\mathrm{T}, \mathrm{P}$ & $00 / 111 / 122$ & $100 / 100$ & $1,4,5,10,13,14,16,20,21,23,24,25$ & $\mathrm{R}$ \\
\hline US-9 & A1 & & $\mathrm{T}$ & $100 / 100$ & $83 / 100$ & & $\mathrm{R}$ \\
\hline US-10 & A2 & $1 \mathrm{a}$ & $\mathrm{P}$ & $111 / 122$ & $100 / 100$ & & $\mathrm{~S}$ \\
\hline US-11 & A1 & IIb & $\mathrm{T}$ & $100 / 100 / 111$ & $100 / 100$ & $1,3,5,6,7,10,13,14,16,18,20,21,24,25$ & $\mathrm{R}$ \\
\hline US-12 & A1 & & $\mathrm{T}, \mathrm{P}$ & $100 / 111$ & $92 / 100$ & $1,5,10,13,14,18,20,21,24,25$ & $\mathrm{R}$ \\
\hline US-13 & $\mathrm{A} 2$ & Ia & $\mathrm{T}$ & $100 / 100$ & $100 / 100$ & & $\mathrm{R}$ \\
\hline US-14 & $\mathrm{A} 2$ & Ia & $\mathrm{P}$ & $100 / 122$ & $100 / 100$ & $1,5,10,13,14,16,20,21,23,24,25$ & $\mathrm{R}$ \\
\hline US-15 & $\mathrm{A} 2$ & Ia & $\mathrm{T}$ & $100 / 100$ & $92 / 100$ & & $\mathrm{~S}$ \\
\hline US-16 & A1 & Ia & $\mathrm{T}$ & $100 / 111$ & $100 / 100$ & $1,5,6,10,13,14,16,18,20,21,24,25$ & $\mathrm{R}$ \\
\hline US-17 & A1 & Ia & $\mathrm{T}, \mathrm{P}$ & $100 / 122$ & $100 / 100$ & $1,3,7,13,14,16,18,20,21,24,25$ & $\mathrm{R}$ \\
\hline US-18 & A2 & Ia & $\mathrm{T}$ & $100 / 100$ & $92 / 100$ & $1,5,10,13,14,16,20,21,24,25$ & $\mathrm{~S}, \mathrm{I}, \mathrm{R}$ \\
\hline US-19 & $\mathrm{A} 2$ & Ia & $\mathrm{T}$ & $100 / 100$ & $92 / 100$ & $1,3,5,7,13,14,16,20,21,24,25$ & $\mathrm{~S}, \mathrm{I}, \mathrm{R}$ \\
\hline US-20 & $\mathrm{A} 2$ & Ia & $\mathrm{T}$ & $100 / 100$ & $100 / 100$ & $1,3,5,7,10,13,14,16,18,20,21,24,25$ & $\mathrm{~S}, \mathrm{I}$ \\
\hline US-21 & A2 & Ia & $\mathrm{T}$ & $100 / 122$ & $100 / 100$ & $1,5,10,13,14,18,20,21,24,25$ & $\mathrm{~S}, \mathrm{I}$ \\
\hline US-22 & A2 & Ia & $\mathrm{T}, \mathrm{P}$ & $100 / 122$ & $100 / 100$ & $1,5,13,14,16,20,21,24,25$ & $\mathrm{~S}, \mathrm{I}$ \\
\hline US-22.1 & A2 & Ia & $\mathrm{T}, \mathrm{P}$ & $100 / 122$ & & $1,5,13,14,16,18,20,21,24,25$ & $\mathrm{~S}$ \\
\hline US-23 & A1 & Ia & $\mathrm{T}, \mathrm{P}$ & $100 / 100$ & $100 / 100$ & $1,2,5,6,10,13,14,17,20,21,24,24 a, 25$ & S,I,R \\
\hline US-24 & A1 & Ia & $\mathrm{P}$ & $100 / 100 / 111$ & $100 / 100$ & $1,3,5,7,10,13,14,16,20,21,23,24,25$ & $\mathrm{~S}, \mathrm{I}$ \\
\hline CA-1 & A1 & & & $86 / 100$ & $92 / 100$ & $1,2,3,4,5,7,9,10,11 \mathrm{a}, 13,14,16,19,20,21,23,24,25$ & \\
\hline CA-2 & A1 & & & $100 / 100$ & $100 / 100$ & $1,3,4,7,13,14,19,20,21,24,25$ & $\mathrm{~S}$ \\
\hline CA-2.1 & A1 & & & $100 / 100$ & $100 / 100$ & $1,3,4,7,13,14,19,20,21,22,24,25$ & \\
\hline CA-3 & A2 & & & $86 / 100$ & $100 / 100$ & $1,2,3,4,5,7,10,13,16,17,20,21,24,25$ & \\
\hline CA-4 & A2 & & $\mathrm{P}$ & $100 / 111$ & $100 / 100$ & $1,10,13,14,16,20,21,24,25$ & $\mathrm{R}$ \\
\hline CA-5 & $\mathrm{A} 2$ & & & $100 / 100$ & $100 / 100$ & $1,5,6,13,14,16,20,21,24,25$ & $\mathrm{~S}$ \\
\hline CA-6 & A2 & & & $100 / 100$ & $100 / 100$ & $1,3,7,10,13,14,18,20,21,24,25$ & $\mathrm{~S}$ \\
\hline CA-7 & $\mathrm{A} 2$ & & & $100 / 100$ & $100 / 100$ & $1,13,14,18,20,21,24,25$ & $\mathrm{~S}$ \\
\hline CA-8 & A1 & & $\mathrm{P}$ & $100 / 111 / 111$ & $100 / 100$ & & \\
\hline CA-9 & A1 & Ia & $\mathrm{T}$ & $100 / 122$ & & $1,5,13,14,16,20,21,24,25$ & $\mathrm{~S}$ \\
\hline
\end{tabular}


Table 1 (continued)

\begin{tabular}{lllllll}
\hline CA-10 & A1 & Ia & T & $100 / 122$ & $1,5,13,14,18,20,21,24,25$ & S \\
CA-11 & A2 & Ia & T & $100 / 100 / 111$ & $1,5,13,14,18,20,21,24,25$ & S \\
\hline
\end{tabular}

Host: $P$ Potato and $T$ Tomato

Metalaxyl: $S$ sensitive, $I$ intermediate, and $R$ resistant

identical to the most common genotype, except for the changes in the allozyme alleles and DNA fingerprints that arose from mutation or mitotic recombination (Goodwin 1997). For example, US-1.2, US-1.3 US-1.5, and US-1.6 variants within the US-1 clonal lineage of $P$. infestans might have originated from mutations at DNA fingerprint loci, while US-1.1 and US-1.4 variants might have originated from mitotic recombination at DNA fingerprint loci that were heterozygous (Goodwin 1997; Goodwin et al. 1994a). The variations within a clonal lineage resulted in characteristic changes such as aggressiveness, growth rate, and colony morphology which allowed for selection by evolutionary processes, such that the selected lines proliferated while the other variants eventually disappeared (Goodwin 1997; Kalischuk et al. 2012). The US6 genotype was introduced into the United States and Canada in the late 1980s from northwestern Mexico near Los Mochis, Sinaloa (Fry and Goodwin 1997b; Smart and Fry 2001). The US-6 genotype (A1 mating type) was the predominant
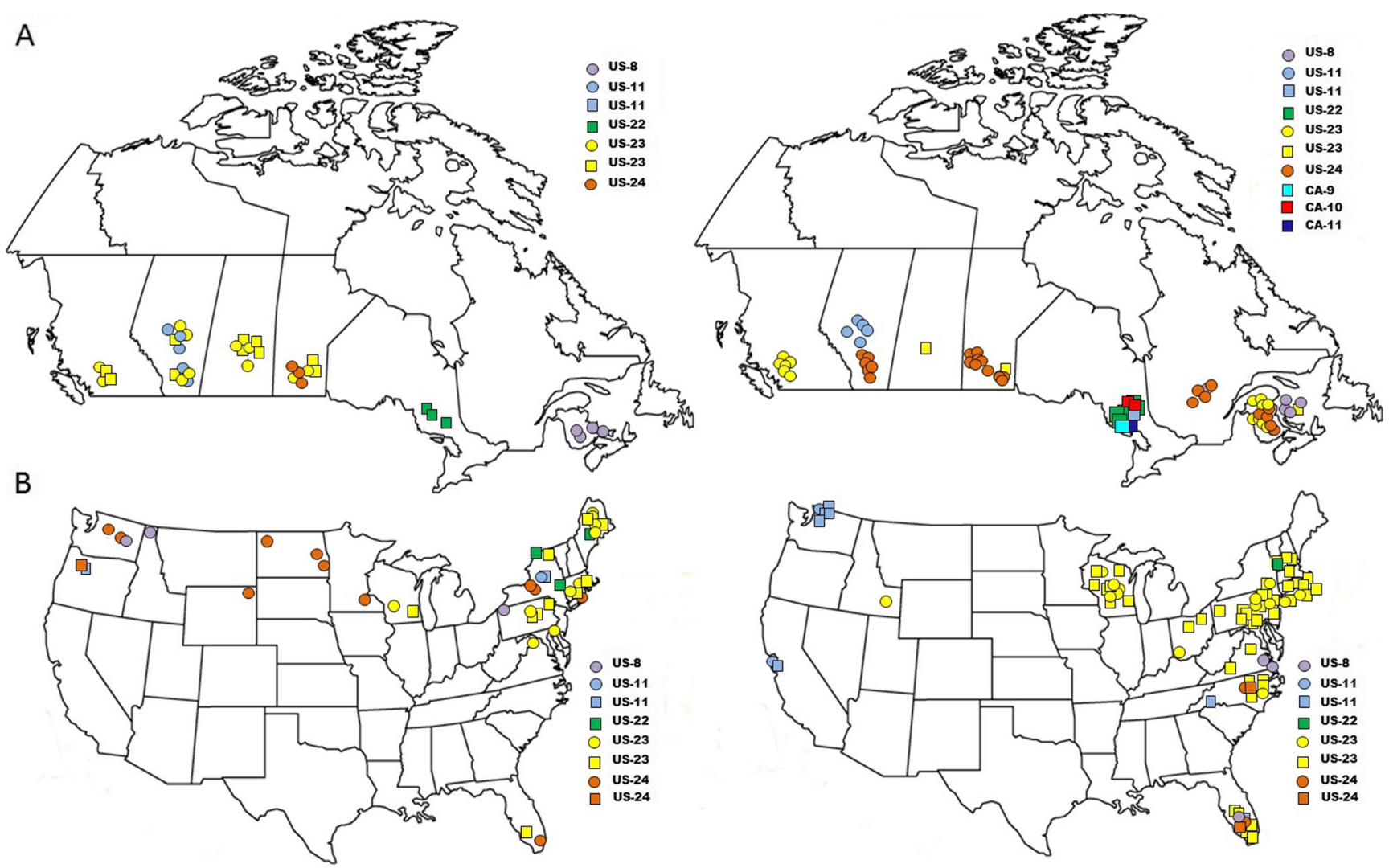

Fig. 3 Population composition of Phytophthora infestans causing late blight in Canada and the United States between 2010 and 2012 shows the ability for complete state or province genotype changes in a single year. Potato samples are indicated by circles and tomato samples are shown as squares. a Locations of $P$. infestans populations and mating type distribution in major potato production areas of Canada in 2010 (left) and 2011 (right), determined from samples exhibiting symptoms of late blight (Kalischuk et al. 2012; Peters et al. 2014). Distribution of the P. infestans isolates shows annual changes and in Ontario the proximity of the genotypes US-11 A1 mating type and US-22 A2 mating type relative to

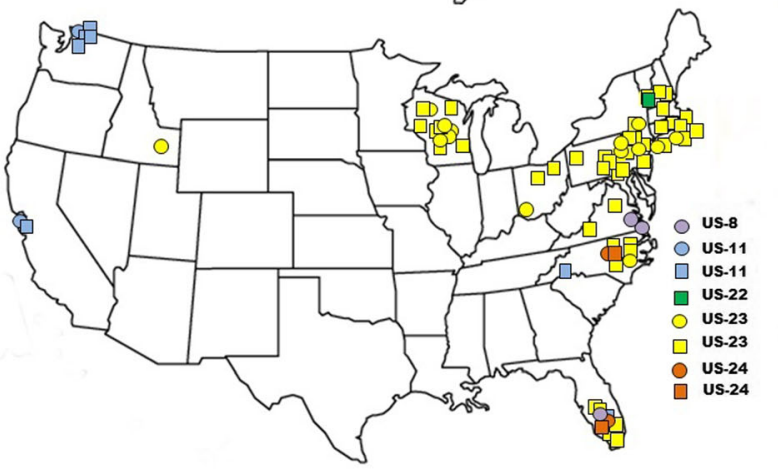

the recombinant genotypes CA-9 A1, CA-10 A1 and CA-11 A2. b Areas show annual changes in the general distribution and diversity of P. infestans genotypes in the United States during 2011 (left) and 2012 (right) (http://usablight.org/map; Hu et al. 2012; Danies et al. 2013; Seidl and Gevens 2013; http://edis.ifas.ufl.edu/pp301). In 2012, the P. infestans US-23 genotype emerged as the dominant clonal lineage in the United States. Continued surveillance will help determine the changing $P$. infestans population composition, frequency of recombination, and characteristics of any new genotypes that threaten potato and tomato production in Canada and the United States 
genotype affecting tomato and potato populations in the United States and Canada from 1987 through 1991, however it was displaced and may now be extinct in the United States. The US-6 genotype infects both the tomato and the potato, but it seems to be particularly virulent on tomato (Goodwin et al. 1994a; Goodwin 1997; Fry and Goodwin 1997a). Thus, it has a survival advantage over the US-1 genotype because it infects both tomato and potato populations.

Prior to 1994, the phenylamide fungicide metalaxyl had been shown to be an effective systemic fungicide providing protection against late blight (Bruck et al. 1980; Fry et al. 1979). However, applications of metalaxyl created selection pressure on the pathogen, leading to the establishment of individuals in the population with increased insensitivity to the fungicide (Daggett et al. 1993). This was evident from the appearance, in the late 1970s, of metalaxyl-resistant isolates of P. infestans in European populations after only a few seasons of fungicide application (Dowley and O'Sullivan 1981). By 1993, the metalaxyl-resistant isolates of the US-7 and US-8 genotypes had displaced the metalaxyl-sensitive isolate of the US-6 genotype (Fraser et al. 1999). The P. infestans US-7 genotype was the predominant in the Columbia Basin of Washington and Oregon during 1993, and was highly pathogenic on tomatoes in addition to potatoes (Goodwin et al. 1998). The $P$. infestans US- 8 genotype was predominant in most other potato-growing areas of Canada and the United States since the mid-1990s and displaced all other genotypes (Fraser et al. 1999; Fry and Goodwin 1997a). The P. infestans US-8 genotype was reported to have greater pathogenic fitness on the potato, with higher infection efficiency, sporulation capacity, and shorter latent period on potato foliage and tubers than other genotypes (Lambert and Currier 1997; Miller et al. 1998). The rapid spread of the US-8 genotype (A2 mating type) was most likely caused by the importation of infected seed tubers (Fraser et al. 1999; Goodwin et al. 1995, 1998).

Migration has introduced $P$. infestans A2 mating types from northwestern Mexico into the United States and Canada and has probably contributed to the occurrence of several new genotypes (Goodwin et al. 1998; Danies et al. 2013; Peters et al. 2014; Table 1). The increased complexity of $P$. infestans populations has coincided with the emergence of aggressive genotypes with fungicide resistance (Goodwin et al. 1995, 1996). For example, the metalaxyl resistant US-11 genotype (A1 mating type) devastated both tomato and potato crops in the United States in 1996 and 1997 (Gavino et al. 2000; Derie and Inglis 2001; Wangsomboondee et al. 2002). The US-11 genotype originated as an especially fit recombinant of the US- 6 and US- 8 genotypes and displaced both the US- 1 and US-6 genotypes. By 1997, US-8 and US-11 were the predominant $P$. infestans genotypes affecting potato and tomato crops (Dorrance et al. 1999; Gavino et al. 2000). Between 1995 and 1998, the P. infestans US-18 and US-19 genotypes (both sensitive to metalaxyl) were affecting tomatoes in North Carolina, while the US-17 genotype was the predominant genotype affecting tomatoes elsewhere in the United States (Fraser et al. 1999; Wangsomnoondee et al. 2002). Recently, the dominant $P$. infestans genotypes on tomato have been US-22 and US-23 which were initially sensitive to metalaxyl but developed insensitivity within a few years (Kalischuk et al 2012; Peters et al. 2014).

Conducive weather conditions and widespread inoculum from infected tomato transplants and seed tubers has contributed to a recent late blight epidemic, causing considerable crop losses in the United States and Canada (Fry et al. 2013). For example, from 2002 to 2007, the P. infestans genotypes US-20 and US-21 were the predominant genotypes affecting tomatoes in North Carolina and Florida (Hu et al. 2012). However, inoculum distribution enabled the US-22 genotype (mating type A2) to rapidly displace the other genotypes and cause significant damage to tomato and potato growing areas in the northeastern United States and central Canada (Hu et al. 2012; Kalischuk et al. 2012). In addition, the new A1 mating type $P$. infestans genotypes US-23 and US-24 were found in tomato and potato-growing areas, respectively, in the northwestern United States and Canada (Kawchuk et al. 2011; Hu et al. 2012; Kalischuk et al. 2012). These genotypes showed evidence of host specialization. For example, isolates of the P. infestans US-23 genotype have been shown to produce considerably more sporangia on tomatoes as compared to potatoes (Danies et al. 2013). Genotypes US-22 and US-23 are pathogenic to both potatoes and tomatoes, although they show a preference for tomatoes, while genotype US-24 is particularly pathogenic on potatoes and less aggressive towards tomatoes (Fry et al. 2013; Rojas et al. 2014). Moreover, recent results indicate a transcontinental distribution of the US-23 P. infestans genotype on infected tomato transplants being sold commercially (Kalischuk et al. 2012). The global movement of new $P$. infestans genotypes, such as US-23 on tomatoes destined for backyard gardens, is a concern as shipments of infected potato seed and tomato transplants increase the genetic diversity in a region beyond the traditional northsouth and east-west corridors of movement (Fry et al. 2013). As a result, the $P$. infestans US-23 genotype is becoming the dominant lineage in both the United States and Canada (Fig. 3).

Fungicides have been critical in preventing late blight, but several prevalent $P$. infestans genotypes have shown a propensity for developing insensitivity to these products. Because widely used site-specific fungicides, such as mefenoxam (the active isomer in metalaxyl), inhibit sporulation and mycelial growth inside host tissues by specifically inhibiting RNA polymearase-1, a mutation that changes the affinity of target sites could easily lead to fungicide resistance (Davidse et al. 1983). Significant variations for mefenoxam sensitivity were identified among $P$. infestans isolates from the different 
genotypes (Hu et al. 2012; Danies et al. 2013; Fry et al. 2013; Kalischuk et al. 2012). Isolates of the US- 8 and US-11 genotypes were resistant to mefenoxam, while isolates of the genotypes US-22, US-23 and US-24 were initially highly sensitive to sensitive to this fungicide. Recent evidence shows a range of mefenoxam resistance among $P$. infestans US-22 and US-23 genotypes (Wijekoon et al. 2014; unpublished data). Studies have shown that a reduced use of fungicides lowers the selection pressure for mefonaxam-resistant strains and mixture with a contact fungicide improves efficacy and may slow the development of resistance to mefonoxam (Dowley and O'Sullivan 1985; Grünwald et al. 2001; Samouch and Cohen 1986). Also, reduced fungicide usage was associated with the recurrence of mefenoxam-sensitive strains. These observations have significant practical implications for late blight management and the continued effectiveness of systemic fungicides to control this disease.

To anticipate possible damage and control actions, and to minimize fungicide applications, late blight prediction models and forecasts based on temperature and moisture have been developed and widely used in many nations, including the United States, Canada, China, New Zealand, Egypt, and India. These models and forecasts typically utilize growth, development, and survival rates determined from experimental studies, and may also use mainly statistical relationships such as logistic regression and discriminant functions (Johnson et al. 1996). BLITECAST and WISDOM are examples of models used for monitoring and forecasting. WISDOM is a widely tested, modified version of BLIGHTCAST developed at the University of Wisconsin (Stevenson 1993). It uses standard weather data such as rainfall, temperature, and relative humidity $(\mathrm{RH})$, to estimate simple predictive parameters such as how long RH exceeds $90 \%$. Other software programs exist that make use of weather data, particularly humidity (e.g., Simblight, Lateblight, NEGfry, Jhulsacast). Improvements to the models have been made by increasing the density and reliability of weather stations distributed for collection of weather data. As is the case with other pests, such as insects and weeds, some related forecasting methods are now GIS-based, and use mapped or geo-referenced weather data as inputs. The previous history of disease at locations of interest and more detailed information such as possible fungicide resistance are believed to enhance predictive capabilities. Availability of inoculum and aspects of the pathogen life cycle may be included in either statistical or process-based modeling approaches (Skelsey et al. 2007, 2009). Additional data on the presence and pressure of the late blight pathogen may be added through the deployment of Rotorod or Burkhard spore traps (Bashi et al. 1982).

\section{Genomic Analysis of Phytophthora Infestans}

The sequenced genome of $P$. infestans strain T30-4 provides the genome organization and gene complement of this pathogen as well as valuable insights into our understanding of the molecular basis of pathogenicity (Haas et al. 2009). The $P$. infestans genome consists of a 240 megabase pair $(\mathrm{Mb})$ sequence with 18,155 protein-coding genes and $74 \%$ repetitive DNA rich in transposable elements (Haas et al. 2009; Raffaele and Kamoun 2012). Results show that the P. infestans genome is comprised of blocks of gene-dense and repeat-poor sequences and blocks of gene-poor and repeat-rich sequences separated by intergenic regions or transposon islands (Gijzen 2009; Haas et al. 2009; Raffaele and Kamoun 2012). It has been suggested that the spread of repetitive sequences and also transposon elements in $P$. infestans might contribute to sequence-exchange mechanisms that rely on homologous recombination. Homologous-recombination within the RLXR and Crinkler (CRN) effector domains would result in higher rates of gene gain and loss, producing variation among pathogen strains that are capable of overcoming plant resistance (Gijzen 2009; Haas et al. 2009). Studies have shown that pathogen genotypes with large and flexible genomes are more likely to adapt faster to produce virulent pathotypes capable of challenging new resistance genes in host plants and new genotypes adapted to new host populations or species (Raffaele and Kamoun 2012; Wulff et al. 2007).

Several genes occupy the gene-sparse, repeat-rich regions of $P$. infestans and are involved in epigenetic processes that result in transcriptional or post-transcriptional modification of gene expression without the alteration of DNA sequence (Haas et al. 2009; Jiang and Tyler 2012; Raffaele et al. 2010a; Slotkin and Martienssen 2007). Small RNA, DNA methylation, and histone modulation can limit gene expression at a target locus or promoter. This may contribute in part to genome plasticity in $P$. infestans by regulating transposon activity and rapid gene expression changes for various characteristics such as host adaptation in lineages (Haas et al. 2009; Jiang and Tyler 2012; Raffaele et al. 2010b).

$P$. infestans has great potential to become virulent on resistant Solanaceous plants (Fry 2008). For P. infestans to successfully infect and colonize its host, it secretes effector proteins that alter host physiology and facilitate colonization by suppressing host defences (Haas et al. 2009; Kamoun and Smart 2005). The effectors secreted by $P$. infestans can be differentiated into two different types depending on their site of action. Apoplastic effectors act in the apoplast space, where they interfere with host defenses. They include inhibitors which act against plant-derived hydrolytic enzymes (protease, lipases, and glucanases) and necrotizing toxins (such as the NLPs proteins and PcF-like cysteine rich inhibitors EPI1 and EPI10 and cysteine protease inhibitors EPIC1 and EPIC2b) (Dong et al. 2014; Haas et al. 2009; Jiang and Tyler 2012; 
Schornack et al. 2009). Cytoplasmic effectors, namely the RXLR and CRN, are characterized by N-terminal signal peptides with conserved motifs that are required for host translocation followed by a highly diverse C-terminal domain that confers effector biochemical activity (Schornack et al. 2009; Win et al. 2007). The RXLR effectors are defined by the conserved N-terminal RXLR-dEER motif that facilitates transport of these effectors into host cells (Haas et al. 2009;
Jiang et al. 2008; Whisson et al. 2007; Win et al. 2012). This domain is functionally equivalent to the conserved $\mathrm{N}$-terminal LXLFLAK motif of CRN effectors (Haas et al. 2009; Schornack et al. 2010; Win et al. 2012). In total, 564 potential RXLR and 196 potential CRN effector genes from the $P$. infestans genome were identified based on the conserved domains and motifs within the N-termini of effectors and computational prediction of secreted signals (Haas et al.

Table 2 Mapped or cloned late blight disease resistance genes derived from Solanum species

\begin{tabular}{|c|c|c|c|}
\hline Linkage & $R$ Gene & Solanum species & References \\
\hline \multirow[t]{6}{*}{ IV } & $R 2$ & demissum & Black et al. (1953), Li et al. (1998), Lokossou et al. (2009) \\
\hline & Rpi-blb3 & bulbocastanum & Lokossou et al. (2009), Park et al. (2005a) \\
\hline & Rpi-abpt & bulbocastanum & Lokossou et al. (2009), Park et al. (2005b) \\
\hline & Rpi-bst1 & brachistotrichum & Hein et al. (2009) \\
\hline & Rpi-mcdl & microdontum & Sandbrink et al. (2000), Tan et al. (2008) \\
\hline & Rpi-snk1.1 & schenckii & Jacobs et al. (2010) \\
\hline $\mathrm{V}$ & $R 1$ & demissum & Black et al. (1953), Ballvora et al. (2002), Leonards-Schippers et al. (1992) \\
\hline \multirow[t]{2}{*}{ VI } & Rpi-blb2 & bulbocastanum & Van der Vossen et al. (2005) \\
\hline & Rpi-ver1 & verrucosum & Jacobs et al. (2010) \\
\hline \multirow[t]{2}{*}{ VII } & Rpil & pinnatisectum & Kuhl et al. (2001) \\
\hline & $P h-1^{*}$ & pimpinellifolium & Peirce (1971) \\
\hline \multirow[t]{4}{*}{ VIII } & $R B$ & bulbocastanum & Naess et al. (2000), Song et al. (2003) \\
\hline & Rpi-stol & stoloniferum & Vleeshouwers et al. (2008), Wang et al. (2008) \\
\hline & Rpi-plt1 & polytrichon & Wang et al. (2008) \\
\hline & Rpi-ptal & papita & Vleeshouwers et al. (2008), Wang et al. (2008) \\
\hline \multirow[t]{8}{*}{ IX } & $R 8$ & demissum & Jo et al. (2011), Malcolmson and Black (1966) \\
\hline & Rpi-phu1 & phureja & Śliwka et al. (2006) \\
\hline & Rpi-vnt1 & venturii & Foster et al. (2009), Pel et al. (2009) \\
\hline & Rpi-mocl & mochiquense & Smilde et al. (2005) \\
\hline & Rpi-dlc1 & dulcamara & Golas et al. (2010) \\
\hline & Rpi-mcq1 & mochiquense & Smilde et al. (2005) \\
\hline & Rpi-carl & caripense & Nakitandwe et al. (2006) \\
\hline & $P h-3^{*}$ & pimpinellifolium & Chunwongse et al. (2002) \\
\hline \multirow[t]{4}{*}{$\mathrm{X}$} & Rpi-berl & berthaultii & Ewing et al. (2000) \\
\hline & Rpi-ber2 & berthaultii & Rauscher et al. (2006), Park et al. (2009a) \\
\hline & Rpi-med & microdontum & Sandbrink et al. (2000) \\
\hline & $P h-2 *$ & pimpinellifolium & Moreau et al. (1998) \\
\hline \multirow[t]{9}{*}{ XI } & $R 3 a$ & demissum & Black et al. (1953), Huang et al. (2004), Huang et al. (2005) \\
\hline & $R 3 b$ & demissum & Huang et al. (2004) \\
\hline & $R 4$ & demissum & Black et al. (1953), Huang et al. (2005) \\
\hline & $R 5$ & demissum & Huang et al. (2005), Malcolmson and Black (1966) \\
\hline & $R 6$ & demissum & El-Kharbotly et al. (1996), Malcolmson and Black (1966) \\
\hline & $R 7$ & demissum & El-Kharbotly et al. (1996), Malcolmson and Black (1966) \\
\hline & $R 10$ & demissum & Bradshaw et al. (2006), Malcolmson (1969) \\
\hline & $R 11$ & demissum & Bradshaw et al. (2006), Malcolmson (1969) \\
\hline & Rpi-cap1 & capsicibaccatum & Jacobs et al. (2010) \\
\hline
\end{tabular}

* Tomato 
2009; Rivas and Genin 2011; Whisson et al. 2007). Because most effectors lack similarity to known enzymes or proteins, it is challenging to elucidate the molecular mechanisms which underlie the role of effectors and the various host targets (Haas et al. 2009; Raffaele and Kamoun 2012; Schornack et al. 2010).

The disease-effector encoding genes, specifically RXRL and $\mathrm{CRN}$, are most frequently located in the repeat-rich regions of the $P$. infestans genome that have been implicated in non-allelic-homologous-recombination (Haas et al. 2009; Raffaele et al. 2010b). This is consistent with the view that effector genes with rapidly evolving C-terminal domains encode for effector proteins which circumvent recognition by the nucleotide binding site leucine-rich repeats domain (NBSLRR) of intracellular host receptor resistance $(R)$ proteins, thereby evading plant defence and facilitating colonization (Haas et al. 2009; Morgan and Kamoun 2007; Kamoun and Smart 2005; Raffaele et al. 2010b). Recombination of the $\mathrm{CRN}$ effectors C-terminal domains occurs at the highlyconserved HVLVXXP motif that marks the junction of the CRN N-terminal and the diverse $\mathrm{C}$-terminal domain, thereby increasing the diversity of effectors and their ability to overcome host resistance (Haas et al. 2009; Raffaele and Kamoun 2012; Schornack et al. 2010).

Hypersensitive late blight resistance is under the control of the plant $R$ genes triggered by a distinct pathogen race carrying Avr genes producing effectors or pathogen-associated molecular patterns (PAMPs) that directly or indirectly elicit resistance and typically follow the gene-for-gene model (Dangl and Jones 2001; Peirce 1971; Song et al. 2003). A zig-zag model has been proposed to explain the recognition and evasion that occurs between the plant-pathogen recognition and interaction that limits the durability of $R$ genes (Jones and Dangl 2006; Hein et al. 2009). Both potatoes and tomatoes have major genes that confer resistance to $P$. infestans, namely the Rpi genes in potatoes and $P h$ genes in tomatoes (Black et al. 1953; Oyarzun et al. 1998; Vleeshouwers et al. 2011). Initially, a total of $11 R$ genes (R1-R11) from Solanum demissum were characterized for potatoes (Table 2). Most of these $R$ genes, $R 3$ through $R 11$ were mapped to chromosome 11 (Bradshaw et al. 2006; El-Kharbotly et al. 1994; Huang et al. 2004, 2005), while $R 1$ (El-Kharbotly et al. 1994), $R 2$ (Li et al. 2008), and $R 8$ (Jo et al. 2011) were mapped to chromosomes 5,4 , and 8 , respectively. These $R$ genes were introduced into cultivated varieties worldwide. However, virulent races of $P$. infestans rapidly evolved to overcome the resistance, as observed for many $R$ genes. More than $30 R$ genes have been identified from wild Solanum species that confer differential resistance to various Solanum species (Vleeshouwers et al. 2011; Table 2). The Ph-1-Ph3 genes from Solanum pimpenellifolium have been characterized for tomatoes (Chen et al. 2008; Panthee and Chen 2010) and Ph-1, $P h-2$, and $P h-3$ were mapped to chromosomes 7, 10, and 9, respectively (Table 2).
Isolation of the $R 1$ gene from $S$. demissum revealed a NBS/ LRR class of protein with a nucleotide binding domain and a leucine rich repeat (Ballvora et al. 2002). Introduction of additional late blight resistant genes such as $R B$ derived from the wild potato relative Solanum bulbocastanum, represents a promising strategy for the development of durable late blight resistant varieties (Song et al. 2003; Fig. 4). However, results show that even recently identified $R$ genes such as RB may be quickly broken and that the $P$. infestans effectors are essential for elicitation and potentially suppression of resistance (Chen et al. 2012). One strategy to increase the durability of disease resistance has been to combine genes into a single variety but incompatibility loci and linkage to undesirable characteristics limits the available combinations. Advances in our understanding of the resistance-avirulence protein interactions will help identify sequences that facilitate the isolation of additional late blight resistance alleles (Vleeshouwers et al. 2008). Ensuring the availability of late blight disease resistant varieties, such as Defender, is a priority for most breeding programs as their introduction will improve yield and quality while supporting sustainable disease management practices (Novy et al. 2006).

Incorporation of late blight resistance into existing varieties through the transformation and production of transgenic lines is critical to the complementation studies required for gene isolation. However, restrictions related to intellectual property protection and consumer acceptance limits these transgenic potatoes to research applications. Recent efforts to develop cisgenic potato varieties through genetic engineering without any foreign sequences should address some consumer concerns (Jacobsen and Schouten 2007). Future efforts will edit specific nucleotides within loci of existing potato varieties through site-directed mutagenesis with zinc finger nuclease (ZFN) and transcription activator-like effector nuclease

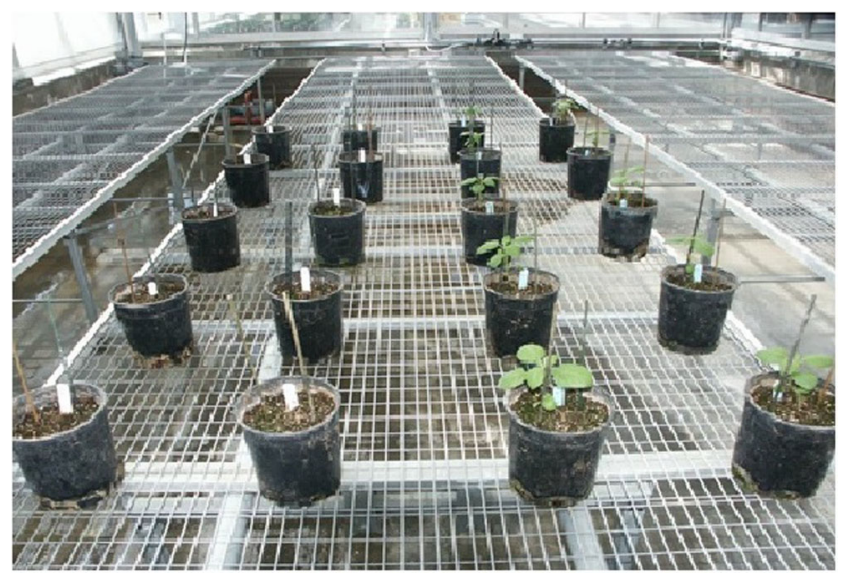

Fig. 4 In planta complementation with the Solanum bulbocastanum RB gene transformed into Shepody. Plants inoculated with the Phytophthora infestans US- 8 genotype were photgraphed 21 days following inoculation. The plants within the left two rows show the severe late blight reaction in the parental Shepody and those in the two rows on the right containing the RB gene developed very limited disease 
(TALEN) mediated homologous recombination (Gaj et al. 2013). The resulting isogenic lines would resemble tomatoes developed for disease resistance through multiple backcrosses and clonal variants of potato selected through somatic embryogenesis (Kawchuk et al. 2001; Nassar et al. 2011). In addition to providing improved late blight resistance in existing and new varieties, sequence editing would facilitate the design of new late blight resistant alleles recognizing epitopes conserved in PAMPs to provide durable protection against emerging races of $P$. infestans.

\section{Conclusions}

The effective management of late blight will be improved by advances in our understanding of $P$. infestans characteristics and host responses. Devastating losses by a particular $P$. infestans population are often associated with the pathogen's ability to overcome specific host resistance, the development of fungicide resistance, the pathogen's adaptation to the changing environment, or some other competitive advantage. Development of new effective fungicides, such as the low environmental impact phosphites and late blight resistant potato varieties should help with sustainable management practices. However, the epidemiology of $P$. infestans continues to be vexing and the Irish potato famine disease still remains the greatest threat to sustainable, global potato production.

Acknowledgments This review is supported in part by the British Columbia Potato \& Vegetable Growers Association, Cavendish Farms, Chipping Potato Growers Association of Manitoba, Conagra Limited Lamb-Weston Division, Potato Growers of Alberta, Saskatchewan Seed Potato Growers Association, Saatzucht-Vertrieb Lange, Agriculture and Agri-Food Canada Project 1751, Alberta Crop Industry Development Fund Ltd. Project 2010C001R, and Saskatchewan Agriculture Development Fund Project 20110095.

Open Access This article is distributed under the terms of the Creative Commons Attribution License which permits any use, distribution, and reproduction in any medium, provided the original author(s) and the source are credited.

\section{References}

Anderson, J.B., and L.M. Kohn. 1995. Clonality in soilborne, plant pathogenic fungi. Annual Review of Phytopathology 33: 369-391.

Ballvora, A., M.R. Ercolano, J. Weiß, K. Meksem, C.A. Bormann, P. Oberhagemann, F. Salamini, and C. Gebhardt. 2002. The R1 gene for potato resistance to late blight (Phytophthora infestans) belongs to the leucine zipper/NBS/LRR class of plant resistance genes. The Plant Journal 30: 361-371.

Bashi, E., Y. Ben-Joseph, and J. Rotem. 1982. Inoculum potential of Phytophthora infestans and the development of potato late blight epidemics. Phytopathology 72: 1043-1047.
Black, W., C. Mastenbroek, W.R. Mills, and L.C. Peterson. 1953. A proposal for an international nomenclature of races of Phytophthora infestans and of genes controlling immunity in Solanum demissum derivates. Euphytica 2: 173-240.

Bourke, P.M.A. 1964. Emergence of potato blight, 1943-46. Nature 203: 805-808.

Bradshaw, J.E., G.J. Bryan, A.K. Lees, K. McLean, and R.M. SolomonBlackburn. 2006. Mapping the R10 and R11 genes for resistance to late blight (Phytophthora infestans) present in the potato (Solanum tuberosum) R-gene differentials of Black. Theoretical and Applied Genetics 112: 744-751.

Bruck, R.I., W.E. Fry, and A.E. Apple. 1980. Effects of metalaxyl and acylalanine fungicide on developmental stages of Phytophthora infestans. Phytopathology 70: 597-601.

Carter, D.A., S.A. Archer, K.W. Buck, D.S. Shaw, and R.C. Shattock. 1990. Restriction fragment length polymorphisms of mitochondrial DNA of Phytophthora infestans. Mycology Research 94: 1123-1128.

Chen, C.H., Z.M. Sheu, and T.C. Wang. 2008. Host specificity and tomato-related race composition of Phytophthora infestans isolates in Taiwan during 2004 and 2005. Plant Disease 92: 751-755.

Chen, Y., Z. Liu, and D.A. Halterman. 2012. Molecular determinants of resistance activation and suppression by Phytophthora infestants effector IPI-O. PLoS Pathogens 8:e1002595.

Chunwongse, J., C. Chunwongse, L. Black, and P. Hanson. 2002. Molecular mapping of the Ph-3 gene for late blight resistance in tomato. Journal of Horticultural Science \& Biotechnology 77: 281-286.

Cohen, Y., S. Farkash, Z. Reshit, and A. Baider. 1997. Oospore production of Phytophthora infestans in potato and tomato leaves. Phytopathology 87: 191-196.

Cooke, D.E.L., and A.K. Lees. 2004. Markers, old and new, for examining Phytophthora infestans diversity. Plant Pathology 53: 692-704.

Cooke, D.E.L., V. Young, P.R.J. Birch, R. Toth, F. Gourlay, J.P. Day, S.F. Carnegie, and J.M. Duncan. 2003. Phenotypic and genotypic diversity of Phytophthora infestans populations in Scotland (1995-97). Plant Pathology 52: 181-192.

Daggett, S.S., E. Gotzand, and C.D. Therrien. 1993. Phenotypic changes in populations of Phytophthora infestans populations from Eastern Germany. Phytopathology 83: 319-323.

Dangl, J.L., and J.D.G. Jones. 2001. Plant pathogens and integrated defence responses to infection. Nature 411: 826-832.

Danies, G., I.M. Small, K. Myers, R. Childers, and W.E. Fry. 2013. Phenotypic characterization of recent clonal lineages of Phytophthora infestans in the United States. Plant Disease 97: 873-881.

Davidse, L.C., A.E. Hofman, and G.C.M. Velthuis. 1983. Specific interference of metalaxyl with endogenous RNA polymerase activity in isolated nuclei from Phytophthora megasperma f. sp.medicaginis. Experimental Mycology 7: 344-361.

Derie, M.L., and D.A. Inglis. 2001. Persistence of complex virulences in populations of Phytophthora infestans in western Washington. Phytopathology 91: 606-612.

Dong, S., R. Stam, L.M. Cano, J. Song, J. Sklenar, K. Yoshida, T.O. Bozkurt, R. Oliva, Z. Liu, M. Tian, J. Win, M.J. Banfield, A.M.E. Jones, R.A.L. van der Hoorn, and S. Kamoun. 2014. Effector specialization in a lineage of the Irish potato famine pathogen. Science 343: 552-555.

Dorrance, A.E., D.A. Inglis, M.L. Derie, C.R. Brown, S.B. Goodwin, W.E. Fry, and K.L. Deahl. 1999. Characterization of Phytophthora infestans populations in Western Washington. Plant Disease 83: 423-428.

Dowley, L.J., and E. O'Sullivan. 1981. Metalaxyl-resistant strains of Phytophthora infestans (Mont.) de Bary in Ireland. Potato Research 24: 417-421.

Dowley, L.J., and E. O'Sullivan. 1985. Monitoring metalaxyl resistance in populations of Phytophthora infestans. Potato Research 28: 531534. 
El-Kharbotly, A., C. Leonards-Schippers, D. Huigen, E. Jacobsen, A. Pereira, W.J. Stiekema, F. Salamini, and C. Gebhardt. 1994. Segregation analysis and RFLP mapping of the R1 and R3 alleles conferring race specific resistance to Phytophthora infestans in progeny of dihaploid potato parents. Molecular and General Genetics 242: 749-754.

El-Kharbotly, A., C. Palomino-Sanchez, F. Salamini, E. Jacobsen, and C. Gebhardt. 1996. R6 and R7 alleles of potato conferring race-specific resistance to Phytophthora infestans (Mont.) de Bary identified genetic loci clustering with the R3 locus on chromosome XI. Theoretical and Applied Genetics 92: 880-884.

Ewing, E.E., I. Šimko, C.D. Smart, M.W. Bonierbale, E.S. Mizubuti, G.D. May, and W.E. Fry. 2000. Genetic mapping from field tests of qualitative and quantitative resistance to Phytophthora infestans in a population derived from Solanum tuberosum and Solanum berthaultii. Molecular Breeding 6: 25-36.

Forbes, G.A., S.B. Goodwin, A. Drenth, P. Oyarzun, M.E. Ordoñez, and W.E. Fry. 1998. A global marker database for Phytophthora infestans. Plant Disease 82: 811-818.

Foster, S.J., T.-H. Park, M. Pel, G. Brigneti, J. Sliwka, L. Jagger, E. van der Vossen, and J.D.G. Jones. 2009. Rpi-vnt1.1, a Tm-22 homolog from Solanum venturii, confers resistance to potato late blight. Molecular Plant-Microbe Interactions 22: 589-600.

Fraser, D.E., P.B. Shoemaker, and J.B. Ristaino. 1999. Characterization of isolates of Phytophthora infestans from tomato and potato in North Carolina from 1993 to 1995. Plant Disease 83: 633638

Fry, W.E. 2008. Phytophthora infestans: the plant (and R gene) destroyer. Molecular Plant Pathology 9: 385-402.

Fry, W.E., and S.B. Goodwin. 1997a. Resurgence of the Irish potato famine fungus. Bioscience. 47: 363-371.

Fry, W.E., and S.B. Goodwin. 1997b. Re-emergence of potato and tomato late blight in the United States. Plant Disease 81: 1349-1357.

Fry, W.E., R.I. Bruck, and C.C. Mundt. 1979. Retardation of potato late blight epidemics by fungicides with eradicant and protectant properties. Plant Disease Reporter 63: 970-974.

Fry, W.E., S.B. Goodwin, A.T. Dyer, J.M. Matuszak, A. Drenth, P.W. Tooley, L.S. Sujkowski, Y.J. Koh, B.A. Cohen, L.J. Spielman, K.L. Deahl, D.A. Inglis, and K.P. Sandlen. 1993. Historical and recent migrations of Phytophthora infestans, chronology, pathways, and implications. Plant Disease 77: 653-661.

Fry, W.E., M.T. McGrath, A. Seaman, T.A. Zitter, A. McLeod, G. Danies, I. Small, K. Myers, K. Everts, A. Gevens, B.K. Gugino, S. Johnson, H. Judelson, H. Ristaino, P. Roberts, G. Secor, K. Seebold, K. Snover-Clift, A. Wyenandt, N.J. Grunwald, and C.D. Smart. 2013. The 2009 late blight pandemic in the eastern United States - Causes and results. Plant Disease 97: 296-306.

Gaj, T., C.A. Gersbach, and C.F. Barbas III. 2013. ZFb, TALEn, and CRISPR/.Cas-based methods for genome engineering. Trends in Biotechnology 31: 397-405.

Gallegly, M.E., and J. Galindo. 1958. Mating types and oospores of Phytophthora infestans in nature in Mexico. Phytopathology 48: 274-277.

Gavino, P.D., C.D. Smart, R.W. Sandrock, J.S. Miller, P.B. Hamm, T.Y. Lee, R.M. Davis, and W.E. Fry. 2000. Implications of sexual reproduction for Phytophthora infestans in the United States: generation of an aggressive genotype. Plant Disease 84: 731-735.

Gijzen, M. 2009. Runaway repeats force expansion of the Phytophthora infestans genome. Genome Biology 10: 241-244.

Golas, T.M., A. Sikkema, J. Gros, R.M.C. Feron, R.G. van den Berg, G.M. van der Weerden, C. Mariani, and J.J.H.M. Allefs. 2010. Identification of a resistance gene Rpi-dlc1 to Phytophthora infestans in European accessions of Solanum dulcamara. Theoretical and Applied Genetics 120: 797-808.

Goodwin, S.B. 1997. The population genetics of Phytophthora. Phytopathology 87: 462-473.
Goodwin, S.B., A. Drenth, and W.E. Fry. 1992. Cloning and genetic analyses of two highly polymorphic, moderately repetitive nuclear DNAs from Phytophthora infestans. Current Genetics 22: 107-115.

Goodwin, S.B., B.A. Cohen, K.L. Deahl, and W.E. Fry. 1994a. Migration from northern Mexico as the probable cause of recent genetic changes in populations of Phytophthora infestans in the United States and Canada. Phytopathology 84: 553-558.

Goodwin, S.B., B.A. Cohen, and W.E. Fry. 1994b. Panglobal distribution of a single clonal lineage of the Irish potato famine fungus. Proceedings of the National Academy of Sciences of the United States 91: 11591-11595.

Goodwin, S.B., L.S. Sujkowski, A.T. Dyer, B.A. Fry, and W.E. Fry. 1995. Direct detection of gene flow and probable sexual reproduction of Phytophthora infestans in northern North America. Phytopathology 85: 473-479.

Goodwin, S.B., L.S. Sujkowski, and W.E. Fry. 1996. Widespread distribution and probable origin of resistance to Metalaxyl in clonal lineages of Phytophtora infestans in the United States and Western Canada. Phytopathology 86: 793-800.

Goodwin, S.B., C.D. Smart, R.W. Sandrock, K.L. Deahl, Z.K. Punja, and W.E. Fry. 1998. Genetic change within populations of Phytophthora infestans in the United States and Canada during 1994 to 1996 : role of migration and recombination. Phytopathology 88: 939949.

Griffith, G.W., and D.S. Shaw. 1998. Polymorphisms in Phytophthora infestans: four mitochondrial haplotypes are detected after PCR amplification of DNA from pure cultures or from host lesions. Applied and Environmental Microbiology 64: 4007-4014.

Grünwald, N.J., and W.G. Flier. 2005. The biology of Phytophthora infestans at its center of origin. Annual Review of Phytopathology 43: $171-190$

Grünwald, N.J., W.G. Flier, A.K. Sturbaum, E. Garay-Serrano, T.B.M. van den Bosch, C.D. Smart, J.M. Matuszak, H. Lozoya-Saldana, L.J. Turkensteen, and W.E. Fry. 2001. Population structure of Phytophthora infestans in the Toluca valley region of central Mexico. Phytopathology 91: 882-890.

Haas, B.J., S. Kamoun, M.C. Zody, R.H.Y. Jiang, R.E. Handsaker, L.M. Cano, M. Grabherr, C.D. Kodira, S. Raffaele, T. Torto-Alalibo, T.O. Bozkurt, A.M.V. Ah-Fong, L. Alvarado, V.L. Anderson, M.R. Armstrong, A. Avrova, L. Baxter, J. Beynon, P.C. Boevink, S.R. Bollmann, J.I.B. Bos, V. Bulone, G. Cai, C. Cakir, J.C. Carrington, M. Chawner, L. Conti, S. Costanzo, R. Ewan, N. Fahlgren, M.A. Fischbach, J. Fugelstad, E.M. Gilroy, S. Gnerre, P.J. Green, L.J. Grenville-Briggs, J. Griffith, N.J. Grünwald, K. Horn, N.R. Horner, C.H. Hu, E. Huitema, D.H. Jeong, A.M.E. Jones, J.D.G. Jones, R.W. Jones, E.K. Karlsson, S.G. Kunjeti, K. Lamour, Z. Liu, L. Ma, D. MacLean, M.C. Chibucos, H. McDonald, J. McWalters, H.J.G. Meijer, W. Morgan, P.F. Morris, C.A. Munro, K. O’Neill, M. Ospina-Giraldo, A. Pinzón, L. Pritchard, B. Ramsahoye, Q. Ren, S. Restrepo, S. Roy, A. Sadanandom, A. Savidor, S. Schornack, D.C. Schwartz, U.D. Schumann, B. Schwessinger, L. Seyer, T. Sharpe, C. Silvar, J. Song, D.J. Studholme, S. Sykes, M. Thines, P.J.I. van de Vondervoort, V. Phuntumart, S. Wawra, R. Weide, J. Win, C. Young, S. Zhou, W. Fry, B.C. Meyers, P. van West, J. Ristaino, F. Govers, P.R.J. Birch, S.C. Whisson, H.S. Judelson, and C. Nusbaum. 2009. Genome sequence and analysis of the Irish potato famine pathogen Phytophthora infestans. Nature 461: 393-398.

Hausner, G., G.D. Inglis, L.J. Yanke, L.M. Kawchuk, and T.A. McAllister. 2000. Analysis of restriction fragment length polymorphisms in the ribosomal DNA of a selection of anaerobic chytrids. Canadian Journal of Botany 78: 917-927.

Haverkort, A.J., P.M. Boonekamp, R. Hutten, E. Jacobsen, L.A.P. Lotz, G.J.T. Kessel, R.G.F. Visser, and E.A.G. van der Vossen. 2008. Societal costs of late blight in potato and prospects of durable 
resistance through cisgenic modification. Potato Research 51: 4757.

Hein, I., P.R.J. Birch, S. Danan, V. Lefebvre, D.A. Odeny, C. Gebhardt, F. Trognitz, and G.J. Bryan. 2009. Progress in mapping and cloning qualitative and quantitative resistance against Phytophthora infestans in potato and its wild relatives. Potato Research 52: 215227.

Hohl, H.R., and K. Iselin. 1984. Strains of Phytophthora infestans with the A2 mating type behaviour. Transactions of the British Mycological Society 83: 529-530.

Hu, C.H., F.G. Perez, R. Donahoo, A. McLeod, K. Myers, K. Ivors, G. Secor, P.D. Roberts, K.L. Deahl, W.E. Fry, and J.B. Ristaino. 2012. Recent genotypes of Phytophthora infestans in eastern United States reveal clonal populations and reappearance of mefenoxam sensitivity. Plant Disease 96: 1323-1330.

Huang, S., V.G. Vleeshouwers, J.S. Werij, R.C. Hutten, H.J. van Eck, R.G. Visser, and E. Jacobsen. 2004. The $R 3$ resistance to Phytophthora infestans in potato is conferred by two closely linked $R$ genes with distinct specificities. Molecular Plant Microbe Interactions 17: 428-435.

Huang, S., E.A. van der Vossen, H. Kuang, V.G. Vleeshouwers, N. Zhang, T.J. Borm, H.J. van Eck, B. Baker, E. Jacobsen, and R.G. Visser. 2005. Comparative genomics enabled the isolation of the $R 3 a$ late blight resistance gene in potato. The Plant Journal 42: 251261.

Jacobs, M.M., B. Vosman, V.G. Vleeshouwers, R.G. Visser, B. Henken, and R.G. van den Berg. 2010. A novel approach to locate Phytophthora infestans resistance genes on the potato genetic map. Theoretical and Applied Genetics 120: 785-796.

Jacobsen, E., and H.J. Schouten. 2007. Cisgenesis strongly improves introgression breeding and induced translocation breeding of plants. Trends in Biotechnology 25: 219-223.

Jiang, R.H.Y., and B.M. Tyler. 2012. Mechanisms and evolution of virulence in oomycetes. Annual review of phytopathology 50: 295-318.

Jiang, R.H., S. Tripathy, F. Govers, and B.M. Tyler. 2008. RXLR effector reservoir in two Phytophthora species is dominated by a single rapidly evolving superfamily with more than 700 members. Proceedings of the National Academy of Sciences of the United States of America 105: 4874-4879.

Jo, K.R., M. Arens, T.Y. Kim, M.A. Jongsma, R.G. Visser, E. Jacobsen, and J.H. Vossen. 2011. Mapping of the S. demissum late blight resistance gene R8 to a new locus on chromosome IX. Theoretical and Applied Genetics 123: 1331-1340.

Jones, J.D., and J.L. Dangl. 2006. The plant immune system. Nature 444: 323-329.

Johnson, D.A., J.R. Alldredge, and D.L. Vakoch. 1996. Potato late blight forecasting models for the semiarid environment of south-central Washington. Phytopathology 86: 480-484.

Kalischuk, M.L., K.I. Al-Mughrabi, R.D. Peters, R.J. Howard, H.W. Platt, and L.M. Kawchuk. 2012. Genetic composition of Phytophthora infestans in Canada reveals migration and increased diversity. Plant Disease 96: 1729-1735.

Kamoun, S., and C.D. Smart. 2005. Late blight of potato and tomato in the genomics era. Plant Disease 89: 692-699.

Kawchuk, L.M., J. Hachey, D.R. Lynch, F. Kulcsar, G. van Rooijen, D.R. Waterer, A. Robertson, E. Kokko, R. Byers, R.J. Howard, R. Fischer, and D. Prüfer. 2001. Tomato Ve disease resistance genes encode cell surface-like receptors. Proceedings of the National Academy of Sciences of the United States of America 98: 65116515

Kawchuk, L.M., R.J. Howard, R.D. Peters, and K.I. Al-Mughrabi. 2011. First report of Phytophthora infestans genotype US-23 causing late blight in Canada. Plant Disease 95: 873.

Knapova, G., and U. Gisi. 2002. Phenotypic and genotypic structure of Phytophthora infestans populations on potato and tomato in France and Switzerland. Plant Pathology 51: 641-663.
Kuhl, J., R. Hanneman, and M. Havey. 2001. Characterization and mapping of Rpi1, a late-blight resistance locus from diploid (1EBN) Mexican Solanum pinnatisectum. Molecular Genetics and Genomics 265: 977-985.

Lambert, D.H., and A.I. Currier. 1997. Differences in tuber rot development for North American clones of Phytophthora infestans. American Potato Journal 74: 39-43.

Lees, A.K., R. Wattier, D.S. Shaw, L. Sullivan, N.A. Williams, and D.E.L. Cooke. 2006. Novel microsatellite markers for the analysis of Phytophthora infestans populations. Plant Pathology 55: 311-319.

Leonards-Schippers, C., W. Gieffers, F. Salamini, and C. Gebhard. 1992. TheR1 gene conferring race-specific resistance to Phytophthora infestans in potato is located on potato chromosome V. Molecular and General Genetics 233: 278-283.

Li, X., H.J. Van Eck, J.R. van der Voort, D.J. Huigen, P. Stam, and E. Jacobsen. 1998. Autotetraploids and genetic mapping using common AFLP markers: the R2 allele conferring resistance to Phytophthora infestans mapped on potato chromosome 4. Theoretical and Applied Genetics 96: 1121-1128.

Li, L., M.J. Paulo, J. Strahwald, J. Lübeck, H.R. Hofferbert, E. Tacke, H. Junghans, J. Wunder, A. Draffehn, F. Eeuwijk, and C. Gebhardt. 2008. Natural DNA variation at candidate loci is associated with potato chip color, tuber starch content, yield and starch yield. Theoretical and Applied Genetics 116: 1167-1181.

Lokossou, A.A., T.-H. Park, G. van Arkel, M. Arens, C. Ruyter-Spira, J. Morales, S.C. Whisson, P.R.J. Birch, R.G.F. Visser, E. Jacobsen, and E.A.G. van der Vossen. 2009. Exploiting knowledge of R/Avr genes to rapidly clone a new LZ-NBS-LRR family of late blight resistance genes from potato linkage group IV. Molecular Plant-Microbe Interactions 22: 630-641.

Malcolmson, J.F. 1969. Races of Phytophthora infestans occurring in Great Britain. Transactions of the British Mycological Society 53: 417-423.

Malcolmson, J.F., and W. Black. 1966. New $R$ genes in Solanum demissum Lindl. and their complementary races of Phytophthora infestans (Mont.) de Bary. Euphytica 15: 199-203.

Mayton, H., C.D. Smart, B.C. Moravec, E.S.G. Mizubuti, A.E. Muldoon, and W.E. Fry. 2000. Oospore survival and pathogenicity of single oospore recombinant progeny from a cross involving the US-8 and US-17 lineages of Phytophthora infestans. Plant Disease 84: 11901196

Miller, J.S., D.A. Johnson, and P.B. Hamm. 1998. Aggressiveness of isolates of Phytophthora infestans from the Columbia Basin of Washington and Oregon. Phytopathology 88: 190-197.

Moreau, P., P. Thoquet, J. Olivier, H. Laterrot, and N. Grimsley. 1998. Genetic mapping of Ph-2, a single locus controlling partial resistance to Phytophthora infestans in tomato. Molecular PlantMicrobe Interactions 11: 259-269.

Morgan, W., and S. Kamoun. 2007. RXLR effectors of plant pathogenic oomycetes. Current Opinion in Microbiology 10: 332-338.

Mosa, A.A., K. Kobayashi, A. Ogoshi, M. Kato, and N. Sato. 1993. Isoenzyme polymorphism and segregation in isolates of Phytophthora infestans from Japan. Plant Pathology 42: 26-34.

Naess, S.K., J.M. Bradeen, S.M. Wielgus, G.T. Haberlach, J.M. McGrath, and J.P. Helgeson. 2000. Resistance to late blight in Solanum bulbocastanum is mapped to chromosome 8. Theoretical and Applied Genetics 101: 697-704.

Nakitandwe, J., F.C. Trognitz, and B.R. Trognitz. 2006. Genetic mapping of Solanum caripense, a wild relative of pepino dulce, tomato and potato, and a genetic resource for resistance to potato late blight. In VI International Solanaceae Conference: Genomics Meets Biodiversity 745: 333-342.

Nassar, A.M.K., J. Abdulnour, Y. Leclerc, X. Li, and D.J. Donnelly. 2011. Intraclonal selection for improved processing of NB 'Russet Burbank' potato. American Journal of Potato Research 88: 387 397. 
Novy, R.G., S.L. Love, D.L. Corsini, J.J. Pavek, J.L. Whitworth, A.R. Mosley, S-R. James, D.C. Hane, C.C. Shock, K.A. Rykbost, C.R. Brown, R.E. Thornton, N.R. Knowles, M.J. Pavek, N. Olsen, and D.A. Inglis. 2006. Defender: a high-yielding processing potato cultivar with foliar and tuber resistance to late blight. American Journal of Potato Research 83: 9-19.

Oyarzun, P.J., A. Pozo, M.E. Ordonez, K. Doucett, and G.A. Forbes. 1998. Host specificity of Phytophthora infestans on tomato and potato in Ecuador. Phytopathology 88: 265-271.

Panthee, D.R., and F. Chen. 2010. Genomics of fungal disease resistance in tomato. Current Genomics 11: 30-39.

Park, T.H., V.G.A.A. Vleeshouwers, D.J. Huigen, E.A.G. Van Der Vossen, H.J. Van Eck, and R.G.F. Visser. 2005a. Characterization and high-resolution mapping of a late blight resistance locus similar to R2 in potato. Theoretical and Applied Genetics 111: 591597.

Park, T.H., V.G. Vleeshouwers, R.C. Hutten, H.J. van Eck, E. van der Vossen, E. Jacobsen, and R.G. Visser. 2005b. High-resolution mapping and analysis of the resistance locus Rpi-abpt against Phytophthora infestans in potato. Molecular Breeding 16: 33-43.

Park, T.H., S. Foster, G. Brigneti, and J.D. Jones. 2009. Two distinct potato late blight resistance genes from Solanum berthaultii are located on chromosome 10. Euphytica 165: 269-278.

Peirce, L.C. 1971. Linkage tests with $P h$ conditioning resistance to race 0, Phytophthora infestans. Tomato Genetics Cooperative Report 21.

Pel, M.A., S.J. Foster, T.-H. Park, H. Rietman, G. van Arkel, J.D.G. Jones, H.J. Van Eck, E. Jacobsen, R.G.F. Visser, and E.A.G. van der Vossen. 2009. Mapping and cloning of late blight resistance genes from Solanum venturii using an interspecific candidate gene approach. Molecular Plant-microbe Interactions 22: 601-615.

Peters, R., K. Al-Mughrabi, M. Kalischuk, K. Dobinson, K. Conn, H. Alkher, M. Islam, F. Daayf, J. Lynn, B. Bizimungu, D. De Koeyer, A. Lévesque, and L. Kawchuk. 2014. Characterization of Phytophthora infestans population diversity in Canada reveals increased migration and genotype recombination. Canadian Journal of Plant Pathology 36: 73-82.

Platt, H.W. 1999. Response of solanaceous cultivated plants and weed species to inoculation with A1 or A2 mating type strains of Phytophthora infestans. Canadian Journal of Plant Pathology 21: 301-307.

Raffaele, S., and S. Kamoun. 2012. Genome evolution in filamentous plant pathogens: why bigger can be better. Nature Reviews Microbiology 10: 417-430.

Raffaele, S., J. Win, L.M. Cano, and S. Kamoun. 2010a. Analyses of genome architecture and gene expression reveal novel candidate virulence factors in the secretome of Phytophthora infestans. BMC Genomics 11: 637.

Raffaele, S., R.A. Farrer, L.M. Cano, D.J. Studholme, D. MacLean, M. Thines, R.H.Y. Jiang, M.C. Zody, S.G. Kunjeti, N.M. Donofrio, B.C. Meyers, C. Nusbaum, and S. Kamoun. 2010b. Genome evolution following host jumps in the Irish potato famine pathogen genotype. Science 330: 1540-1543.

Rauscher, G.M., C.D. Smart, I. Simko, M. Bonierbale, H. Mayton, A. Greenland, and W.E. Fry. 2006. Characterization and mapping of R Pi-ber, a novel potato late blight resistance gene from Solanum berthaultii. Theoretical and Applied Genetics 112: 674-687.

Rivas, S., and S. Genin. 2011. A plethora of virulence strategies hidden behind nuclear targeting of microbial effectors. Frontiers in Plant Science 2: 104.

Rojas, J.A., W.W. Kirk, E. Gachango, D.S. Douches, and L.E. Hanson. 2014. Tuber Blight development in potato cultivars in response to different genotypes of Phytophthora infestans. Journal of Phytopathology 162: 33-42.

Samouch, Y., and Y. Cohen. 1986. Efficacy of systemic and contact fungicide mixtures in controlling late blight in potatoes. Phytopathology 76: 855-859.
Sandbrink, J.M., L.T. Colon, P.J. Wolters, and W.J. Stiekema. 2000. Two related genotypes of Solanum microdontum carry different segregating alleles for field resistance to Phytophthora infestans. Molecular Breeding 6: 215-225.

Schornack, S., E. Huitema, L.M. Cano, T.O. Bozkurt, R. Oliva, M. van Damme, S. Schwizer, S. Raffaele, A. Chaparro-Garcia, R. Farrer, M.E. Segretin, J. Bos, B. Haas, M.C. Zody, C. Nusbaum, J. Win, M. Thines, and S. Kamoun. 2009. Ten things to know about oomycete effectors. Molecular Plant Pathology 10: 795-803.

Schornack, S., M. Van Damme, T.O. Bozkurt, L.M. Cano, M. Smoker, M. Thines, E. Gaulin, S. Kamoun, and E. Huitmema. 2010. Ancient class of translocated oomycete effectors targets the host nucleus. Proceedings of the National Academy of Sciences of the United States of America 107: 17421-17426.

Seidl, A.C., and A.J. Gevens. 2013. Characterization and distribution of three new clonal lineages of Phytophthora infestans causing late blight in Wisconsin from 2009 to 2012. American Journal of Potato Research 90: 551-560.

Skelsey, P., W. van der Werf, G.J.T. Kessel, W.A.H. Rossing, and A.A.M. Holtslag. 2007. Multi-scale modelling of infection pressure from Phytophthora infestans. Bulletin OEPP 37: 313-316.

Skelsey, P., G.J.T. Kessel, A.A.M. Holtslag, A.F. Moene, and W. van der Werf. 2009. Regional spore dispersal as a factor in disease risk warnings for potato late blight: A proof of concept. Agricultural and Forest Meteorology 149: 419-430.

Śliwka, J., H. Jakuczun, R. Lebecka, W. Marczewski, C. Gebhardt, and E. Zimnoch-Guzowska. 2006. The novel, major locus Rpi-phu1 for late blight resistance maps to potato chromosome IX and is not correlated with long vegetation period. Theoretical and Applied Genetics 113: 685-695.

Slotkin, R.K., and R. Martienssen. 2007. Transposable elements and the epigenetic regulation of the genome. Nature Reviews. Genetics 8: 272-285.

Smart, C.D., and W.E. Fry. 2001. Invasions by the late blight pathogen: renewed sex and enhanced fitness. Biological Invasions 3: 235-243.

Smilde, W.D., G. Brigneti, L. Jagger, S. Perkins, and J.D.G. Jones. 2005. Solanum mochiquense chromosome IX carries a novel late blight resistance gene Rpi-moc1. Theoretical and Applied Genetics 110: $252-258$.

Sogin, M.L., and J.D. Silberman. 1998. Evolution of the protists and protistan parasites from the perspective of molecular systematics. International Journal for Parasitology 28: 11-20.

Song, J., J.M. Bradeen, S.K. Naess, J.A. Raasch, S.M. Wielgus, G.T. Haberlach, J. Liu, H. Kuang, S. Austin-Phillips, C.R. Buell, J.P. Helgeson, and J. Jiang. 2003. Gene RB cloned from Solanum bulbocastanum confers broad spectrum resistance to potato late blight. Proceedings of the National Academy of Sciences of the United States of America 100: 9128-9233.

Spielman, L.J., A. Drenth, L.C. Davidse, L.J. Sujkowski, W. Gu, P.W. Tooley, and W.E. Fry. 1991. A second world-wide migration and population displacement of Phytophthora infestans? Plant Pathology 40: 422-430.

Stevenson, W.R. 1993. IPM for potatoes: a multifaceted approach to disease management and information delivery. Plant Disease 77: 309-311.

Tan, M.A., R.C. Hutten, C. Celis, T.H. Park, R.E. Niks, R.G. Visser, and H.J. van Eck. 2008. The RPi-mcd1 locus from Solanum microdontum involved in resistance to Phytophthora infestans, causing a delay in infection, maps on potato chromosome 4 in a cluster of NBS-LRR genes. Molecular Plant-Microbe Interactions 21: 909-918.

Tooley, P.W., W.E. Fry, and M.J. Villarreal-Gonzalez. 1985. Isozyme characterization of sexual and asexual Phytophthora infestans populations. The Journal of Heredity 76: 431-435.

Vleeshouwers, V.G.A.A., H. Rietman, P. Krenek, N. Champouret, C. Young, S.-K. Oh, M. Wang, K. Bouwmeester, B. Vosman, R.G.F. 
Visser, E. Jacobsen, F. Govers, S. Kamoun, and E.A.G. van der Vossen. 2008. Effector genomics accelerates discovery and functional profiling of potato disease resistance and Phytophthora infestans avirulence genes. PLoS One 3: e2875.

Vleeshouwers, V.G., S. Raffaele, J. Vossen, N. Champouret, R. Oliva, M.E. Segretin, H. Rietman, L.M. Cano, A. Lokossou, G. Kessel, M.A. Pel, and S. Kamoun. 2011. Understanding and exploiting late blight resistance in the age of effectors. Annual Review of Phytopathology 49: 507-531.

Vossen, E.A.G., J. Gros, A. Sikkema, M. Muskens, D. Wouters, P. Wolters, A. Pereira, and S. Allefs. 2005. The Rpi-blb2 gene from Solanum bulbocastanum is an Mi-1 gene homolog conferring broad-spectrum late blight resistance in potato. The Plant Journal 44: 208-222.

Wang, M., S. Allefs, R.G. van den Berg, V.G. Vleeshouwers, E.A. van der Vossen, and B. Vosman. 2008. Allele mining in Solanum: conserved homologues of Rpi-blb1 are identified in Solanum stoloniferum. Theoretical and Applied Genetics 116: 933-943.

Wangsomboondee, T., C.T. Groves, P.B. Shoemaker, M.A. Cubeta, and J.B. Ristaino. 2002. Phytophthora infestans populations from tomato and potato in North Carolina differ in genetic diversity and structure. Phytopathology 92: 1189-1195.

Whisson, S.C., P.C. Boevink, L. Moleleki, A.O. Avrova, J.G. Morales, E.M. Gilroy, M.R. Armstrong, S. Grouffaud, P. van West, S. Chapman, I. Hein, I.K. Toth, L. Pritchard, and P.R. Birch. 2007. A translocation signal for delivery of oomycete effector proteins into host plant cells. Nature 450: 115-118.

Wijekoon, C.P., R.D. Peters, K.I. Al-Mughrabi, and L.M. Kawchuk. 2014. First report of late blight caused by Phytophthora infestans clonal lineage US-23 on tomato and potato in Atlantic Canada. Plant Disease 98: 426.

Win, J., W. Morgan, J. Bos, K.V. Krasileva, L.M. Cano, A. ChaparroGarcia, R. Ammar, B.J. Staskawicz, and S. Kamoun. 2007. Adaptive evolution has targeted the C-Terminal domain of the RXLR effectors of plant pathogenic oomycetes. The Plant Cell 19: 2349-2369.

Win, J., K.V. Krasileva, S. Kamoun, K. Shirasu, B.J. Staskawicz, and M.J. Banfield. 2012. Sequence divergent RXLR effectors share a structural fold conserved across plant pathogenic oomycete species. PLoS Pathogens 8: e1002400.

Wulff, G.E., W. Pervez, J.R. Nelson, M. Bonierable, A.J. Landeo, and A.G. Forbes. 2007. Identification of stable resistance to Phytophthora infestans in potato genotypes evaluated in field experiments in Peru. Experimental Agriculture 43: 353363.

Yoshida, K., V.J. Schuenemann, L.M. Cano, M. Pais, B. Mishra, R. Sharma, C. Lanz, F.N. Martin, S. Kamoun, J. Krause, M. Thines, D. Weigel, and H.A. Burbano. 2013. The rise and fall of the Phytophthora infestans lineage that triggered the Irish potato famine. eLIFE 2: $\mathrm{e} 00731$. 